\title{
Production of Biogas and Biofertilizer by the Co-digestion of Effluent From Cellulose Industry With Addition of Glycerin
}

\author{
M. L. Veroneze ${ }^{1}$, D. Schwantes ${ }^{2}$, A. C. Gonçalves Jr. ${ }^{1}$, J. Manfrin ${ }^{1}$, A. P. Schiller ${ }^{1}$, T. B. Schuba ${ }^{1}$, \\ A. Richart $^{3} \&$ V. Schwantes ${ }^{1}$ \\ ${ }^{1}$ State University of Western Paraná, Paraná State, Brazil \\ ${ }^{2}$ Educational College of Medianeira, State of Paraná, Brazil \\ ${ }^{3}$ Pontifical Catholic University of Paraná, Parana State, Brazil \\ Correspondence: Daniel Schwantes, Educational College of Medianeira, 1820 Rio Branco Street, Downtown, \\ Medianeira, State of Paraná, Zipcode: 85884-000, Brazil. E-mail: daniel_schwantes@hotmail.com
}

Received: October 21, 2018

doi:10.5539/jas.v11n3p242
Accepted: November 30, $2018 \quad$ Online Published: February 15, 2019

URL: https://doi.org/10.5539/jas.v11n3p242

\begin{abstract}
The present study aimed to assess the anaerobic digestion of sewage from cellulose industry mixed with doses of glycerin, in order to produce biofertilizer and biogas, for agriculture and energy purposes. Five anaerobic reactors were developed, which were fed with effluent and doses of glycerin $\left(0,5,10,15\right.$ and $\left.20 \% \mathrm{v} \mathrm{v}^{-1}\right)$ and evaluated during the hydraulic retention time of 42 days. The physical and chemical parameters were evaluated every seven days: temperature; $\mathrm{pH}$; turbidity; series of solids; total phosphorus $\left(\mathrm{P}_{\text {total }}\right)$; Kjeldahl nitrogen $\left(\mathrm{N}_{\text {total }}\right)$ and $\mathrm{COD}$; as well as the levels of $\mathrm{K}, \mathrm{Ca}, \mathrm{Mg}, \mathrm{Cu}, \mathrm{Zn}, \mathrm{Fe}, \mathrm{Mn}$ and $\mathrm{Cd}, \mathrm{Pb}$ and $\mathrm{Cr}$; biogas production was evaluated daily. The anaerobic treatment produced biofertilizer with excellent nutritional conditions, with adequate levels of $\mathrm{P}, \mathrm{K}, \mathrm{Ca}, \mathrm{Mg}, \mathrm{Mn}, \mathrm{Fe}$ and $\mathrm{Zn}$. The addition of glycerin increased biogas production, with $15 \%$ and $5 \%$ of glycerin, respectively producing 0.54 and $0.40 \mathrm{~mL} \mathrm{~L}^{-1} \mathrm{~d}^{-1}$. The treatments of $15 \%$ and $5 \%$ of v v glycerin also exhibited greater removal of COD. However, the low levels of $\mathrm{N}$ have caused problems in the anaerobic process. Anaerobic digestion of the cellulose industry effluent with 5 and $15 \%$ of glycerin $\left(\mathrm{v} \mathrm{v}^{-1}\right)$ provided increase in biogas production of 0.54 and $0.40 \mathrm{~mL} \mathrm{~L}^{-1} \mathrm{~d}^{-1}$, respectively. $\mathrm{K}, \mathrm{Ca}, \mathrm{Mg}, \mathrm{Zn}, \mathrm{Fe}$ and $\mathrm{Mn}$ at the final biodigestion remained with excellent levels for use in crops as biofertilizer.
\end{abstract}

Keywords: renewable energy, bioenergy, glycerin, biodigestion, biofuels

\section{Introduction}

Brazil is a major world producer of paper, besides supplying the domestic market, it exports products mainly to countries of Latin America, the European Union and North America (Bracelpa, 2013).

This industrial segment is one of the most competitive in the country, the quality standard is one of the best in world, and the market is globalized and strongly active. The majority of paper production comes from the pulp of short eucalyptus fibers, which the country is the largest producer in the world. These fibers are mainly used in the manufacture of papers with high benefit (Montebello \& Bacha, 2013).

In contrast to the considerable economic benefits, the pulp and paper industry is responsible for the emission of pollutants in the solid, liquid and gaseous states (CETESB, 2008). The sector generates a large amount of effluent, reaching a value of $1 \mathrm{~m}^{3}$ per ton of produced paper (Priadi et al., 2014), and therefore has been seeking development in environmental issues, especially liquid effluents generated in production processes, which, due to highly polluting characteristics and high volume, when released without adequate treatment, aggressively impair the quality of the receiving water body (CETESB, 2008).

Among the new technologies that have emerged in recent years, which can be applied in the treatment of effluents from the pulp and paper industries, effluent co-digestion has gained prominence because, besides biostabilizing the effluent, it enables the production of biogas during the process. The addition of glycerin to the effluent may potentiate the biogas production, making it an activity of greater attractiveness and profitability (Priadi et al., 2014).

Some studies have demonstrated that anaerobic digestion of crude glycerin, mixed with effluents from different 
origins, is an excellent option to make the treatment of these wastes more efficient (Orrico Jr. et al., 2016).

Crude glycerin is a residue from the biodiesel production process. In general the production of biodiesel is carried out by the catalyzed transesterification process. In addition to the desired methyl esters, such reaction also provides some other products, including glycerin and pressed oil pie. All these by-products provide attractive raw materials for use in the production of biogas (Kolesárová et al., 2011).

However, the introduction of biodiesel into the Brazilian energy matrix by the National Program for the Production and Use of Biodiesel has increased the supply of glycerin, which is produced at the rate of $10 \mathrm{~kg}$ for every $100 \mathrm{~L}$ of biodiesel (Larsen et al., 2013).

In this context, the process of anaerobic biodigestion of residues from different origins and compositions, in this case, effluents from cellulose and the biodiesel industries, may be characterized as a solution to improve the treatment and biostabilization of these, possibly increasing production of biogas, and, in addition, enabling the correct destination of this waste, for its eventual use as a biofertilizer in agriculture.

The objective of the present study was to evaluate the process of co-digestion of the effluents from the cellulose industry with added doses of glycerin, aiming the production of biogas, as well as the possibility of biofertilizer production.

\section{Methods}

\subsection{Development of Alternative Anaerobic Reactors}

The biodigestors were constructed with recycled plastic material, for that, 5 plastic bottles with capacity of 50 liters were used; 5 taps; 4.5 meters of hose Rodoar soft blue PU $8 \mathrm{~mm} ; 5$ metal and silicone fittings used for sealing, keeping the internal environment completely anaerobic.

The taps were installed to allow sampling of the liquid effluent along the hydraulic retention time (HRT), the reactors were arranged horizontally, with the end containing the tap down and a spigot, facing upwards (Figure 1A).
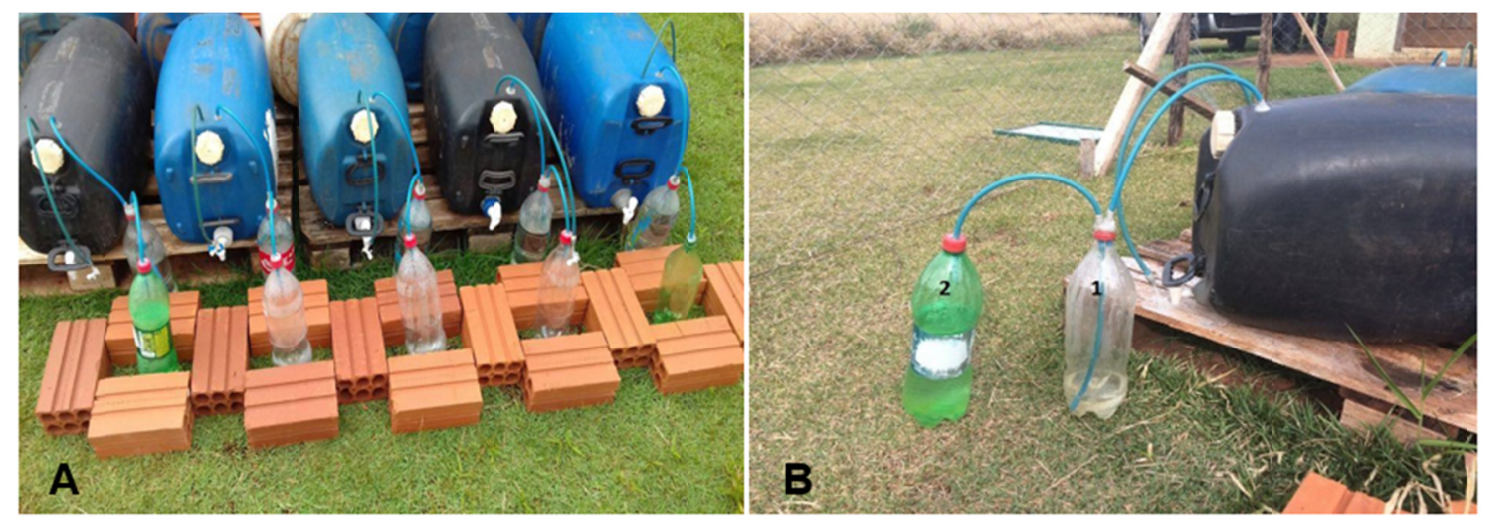

Figure 1. Biodigesters and gasometer linked to the reactor used in the experiment

\subsection{Experiment Setup and Doses of Glycerin}

The experiment was carried out at the Pontifical Catholic University of Paraná (PUCPR), located in the municipality of Toledo, Paraná $\left(24^{\circ} 43^{\prime} 08.72^{\prime \prime} \mathrm{S}\right.$ and $\left.53^{\circ} 46^{\prime} 08.72^{\prime \prime} \mathrm{W}\right)$ with an average elevation of 575 meters.

Before the supply of the biodigestors, physical and chemical parameters of the cellulose industry effluent were analyzed, in order to evaluate the efficiency of the process.

The volume of 25 liters of effluent were added in each biodigester, as well as increasing doses of glycerin $(5,10,15$ and $20 \% \mathrm{v} \mathrm{v}^{-1}$ ). The biodigesters were operated without maintenance of temperature, with hydraulic retention time (HRT) of 42 days, with daily monitoring of gas volume and weekly monitoring of physical and chemical parameters of the effluent.

In Table 1 are exhibited the data regarding the amount of cellulose effluent and glycerin (Vetec $\AA, 99.5 \%$ ) added to the biodigesters. 


\subsection{Gasometer}

Five gasometers were made in plastic bottles, which were filled with water and sealed with a lid to which two hoses were connected, one for biogas inlet and another for the water outlet. As the gas was produced, it was directed through the hoses for the bottles, the volume of biogas produced ended up generating pressure and displacing the water to a second bottle, thus providing quantification of the volume of the produced gas (Figure 1B).

For the construction of the gasometers, 10 plastic bottles of 2 liters were used; 4.5 meters of hose Rodoar soft blue PU $8 \mathrm{~mm}$; 5 metal fittings; 5 plastic valves and silicone for sealing.

\subsection{Sampling of Waste and Evaluated Parameters}

The cellulose effluent sampling was carried out in a pulp paper production unit located in the state of Paraná, southern Brazil.

Physical and chemical parameters evaluated were: $\mathrm{pH}$; turbidity; total (TS), fixed (FS) and volatile (VS) solids; total phosphorus $\left(\mathrm{P}_{\text {total }}\right)$; total nitrogen $\left(\mathrm{N}_{\text {Kjeldahl }}\right)\left(\mathrm{N}_{\text {total }}\right)$, and chemical oxygen demand (COD) (APHA, 2012).

Table 1. Doses of glycerin and total volume of biodigesters

\begin{tabular}{llll}
\hline Doses of glycerin $\%\left(\mathrm{v} \mathrm{v}^{-1}\right)$ & Cellulose industry effluent $(\mathrm{L})$ & Glycerin $(\mathrm{L})$ & Total volume of the mixture $(\mathrm{L})$ \\
\hline 0 & 25.00 & 0.00 & 25.00 \\
5 & 23.75 & 1.25 & 25.00 \\
10 & 22.50 & 2.50 & 25.00 \\
15 & 21.25 & 3.75 & 25.00 \\
20 & 20.00 & 5.00 & 25.00 \\
\hline
\end{tabular}

Note. Amount of cellulose effluent and glycerin (Vetec $₫$, $99.5 \%$ ) exposed to biodigesters.

Total concentration of potassium $(\mathrm{K})$, calcium $(\mathrm{Mg})$, copper $(\mathrm{Cu})$, zinc $(\mathrm{Zn})$, iron $(\mathrm{Fe})$, manganese $(\mathrm{Mn})$, cadmium $(\mathrm{Cd})$, lead $(\mathrm{Pb})$ and chromium $(\mathrm{Cr})$ were determined by atomic absorption spectrometry, flame mode (FAAS) model GBC 932 AA (Victoria, Australia) with deuterium lamp for background correction (Welz and Sperling, 1999).

In addition, the volume of the biogas produced was determined daily, by the gasometers linked to the biodigesters, the measurement was carried out with graduated cylinder.

\section{Results}

The reactor containing $0 \%$ of glycerin exhibited low variation of $\mathrm{pH}$, with maximum and minimum values of 6.16 to 6.81 . The presence of glycerin acidified the medium, reaching the lowest $\mathrm{pH}(4.77)$ in the dose of $15 \%$.

The higher the dose of glycerin added to the system, the higher is the concentration of TS, because with such increase, the concentration of VS is increased, since the glycerin $\left[\mathrm{C}_{3} \mathrm{H}_{5}(\mathrm{OH})_{3}\right]$ is basically composed of carbon, hydrogen and oxygen. In addition to increasing TS levels, the addition of glycerin favors the production of biogas components, mainly $\mathrm{CH}_{4}, \mathrm{CO}_{2}, \mathrm{NH}_{3}$ and $\mathrm{H}_{2} \mathrm{~S}$.

The turbidity is higher in the glycerin treatments than in the $0 \%$ dose treatment, due to the multiplication of microorganisms.

The treatments with glycerin addition exhibited higher values for COD, this is an expected fact, since a liquid with higher turbidity and total and volatile solids tends to have higher COD values.

In this research, the treatments with the highest COD removal at the end of HRT are the treatments with the highest biogas production (Dose $0 \%, 5 \%$ and $15 \%$ ).

Both, the industrial effluent and the glycerin, did not have $\mathrm{N}$ contents in their initial composition, a condition that was maintained for almost all treatments until the end of the process.

It was observed a reduction of Ptotal for the treatments with glycerin addition. The stability of $\mathrm{P}$ becomes attractive for biofertilization purposes, since the final effluent contains considerable $\mathrm{P}$ contents, being this one of the most important macronutrients for the development of plants. 
The doses of $15 \%$ and $5 \%$ of glycerin, respectively, resulted in higher rate of biogas production $(0.543$ and 0.400 $\left.\mathrm{mL} \mathrm{L}^{-1} \mathrm{~d}^{-1}\right)$. Doses higher than $15 \%$ affected the development of microorganisms and, consequently, the production of biogas.

That most of the studied nutrients had their levels elevated throughout HRT. In general, we observed a significant increase of the final $\mathrm{K}, \mathrm{Ca}, \mathrm{Mg}$ contents of the bio stabilized effluent, as well as the maintenance and availability of $\mathrm{Fe}, \mathrm{Mn}$ in the glycerin treatments, as a function of the maintenance of the liquid medium at more acidic $\mathrm{pH}$, facilitating more soluble forms in the aqueous medium.

\section{Discussion}

The acidification of the medium occurs due to the presence of the glycerin, which directly affects the microbial metabolism inside the digesters, causing a substantial increase of the substrate (organic material) and raising the population of bacteria quickly, thus provoking the presence of organic acids in the biodigester origin of the acidogenic phase (Simm et al., 2017).

According to Figure 2, the reactor containing $0 \%$ of glycerin exhibited low variation of $\mathrm{pH}$ similar to Priadi et al. (2014), when evaluating the biogas production from the anaerobic digestion of effluent from the cellulose industry found a variation of 6.30 to 6.90 , considered by the authors as low fluctuation range and with adequate $\mathrm{pH}$ values for the development of methanogens.

According to Ruiz et al. (2017), the pH drop of the effluent is due to the accumulation of these organic acids in the biodigester, which occurs when the system is unable to use all the material coming from the steps of hydrolysis and acidogenesis in the next phase, that is, in the methanogenic phase.

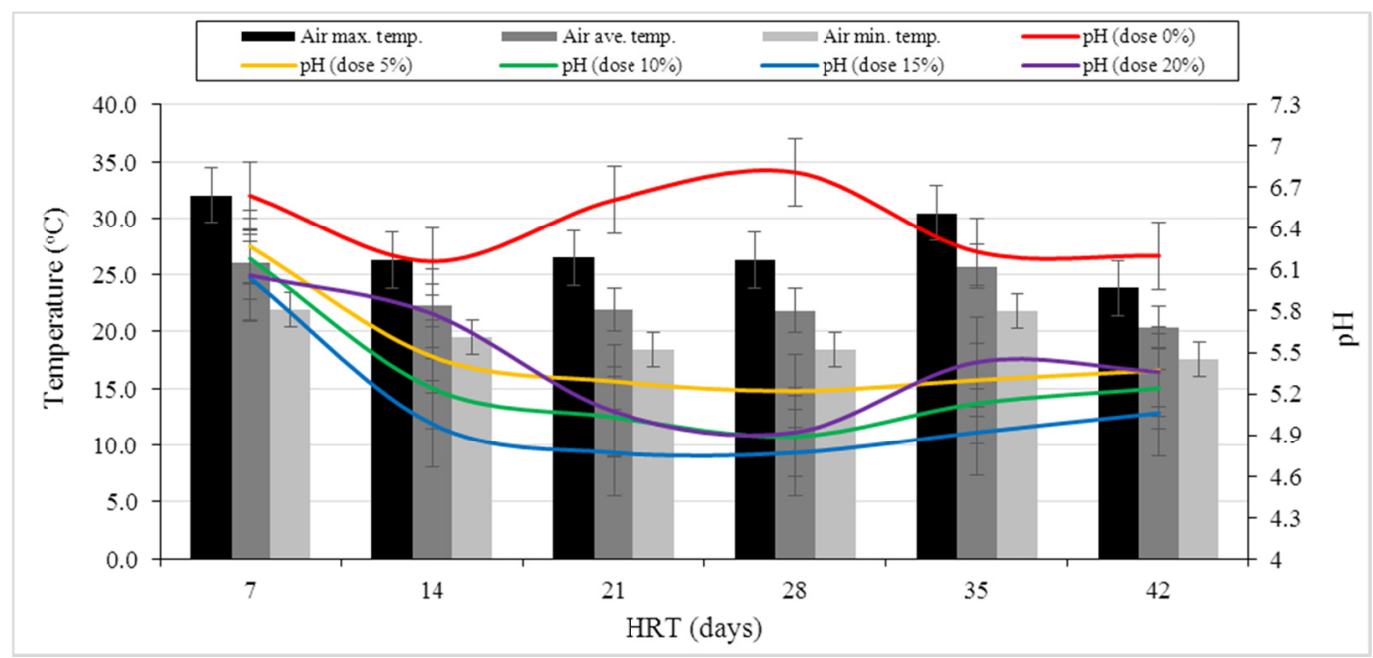

Figure 2. $\mathrm{pH}$ and air temperature (mean, maximum and minimum, in ${ }^{\circ} \mathrm{C}$ ) during the anaerobic co-digestion of industrial effluent (cellulose) with glycerin doses $\left(0,5,10,15\right.$ and $\left.20 \% \mathrm{v} \mathrm{v}^{-1}\right)$, during the hydraulic retention time (HRT) of 42 days

Acid or alkaline $\mathrm{pH}$ values negatively influence the metabolism of methanogenic microorganisms, the ones responsible for the production of methane $\left(\mathrm{CH}_{4}\right)$, which are quite sensitive to variations in the $\mathrm{pH}$ of the medium. Calli et al. (2005) state that inhibition of biogas production may occur at $\mathrm{pH}$ values above 7.4. In general, low $\mathrm{pH}$ systems are not able to produce buffer solution to maintain $\mathrm{pH}$ stability, and it is necessary to alkalinize the medium to raise biogas and methane production (Awe et al., 2017).

At first, the anaerobic microorganisms perform anabolic reactions, aiming their cellular growth. In this way, by means of enzymatic processes, there is a breakdown of the substrate (effluent and glycerin components) and assimilation by the bacterial cells (anaerobic digestion phases, such as hydrolysis, acidogenesis, acetogenesis and methanogenesis) (Shah et al., 2014).

In this initial stage, due to the high availability of nutrients in the effluent, intense multiplication of microorganisms occurs (exponential and stationary phase of microorganisms development) (Shah et al., 2014), resulting in turbidity increase, since the microorganisms are also biomass particulate matter or suspension 
(Jerônimo et al., 2012). This also explains the fact that turbidity is higher in glycerin treatments than in the treatment with $0 \%$ Dose.

In this initial stage, the intense multiplication of microorganisms result in a marked increase in turbidity, since the microorganisms are also particulate biomass, or biomass suspension (Jerônimo et al., 2012). This also explains the fact that turbidity is higher in glycerin treatments than in Dose $0 \%$.

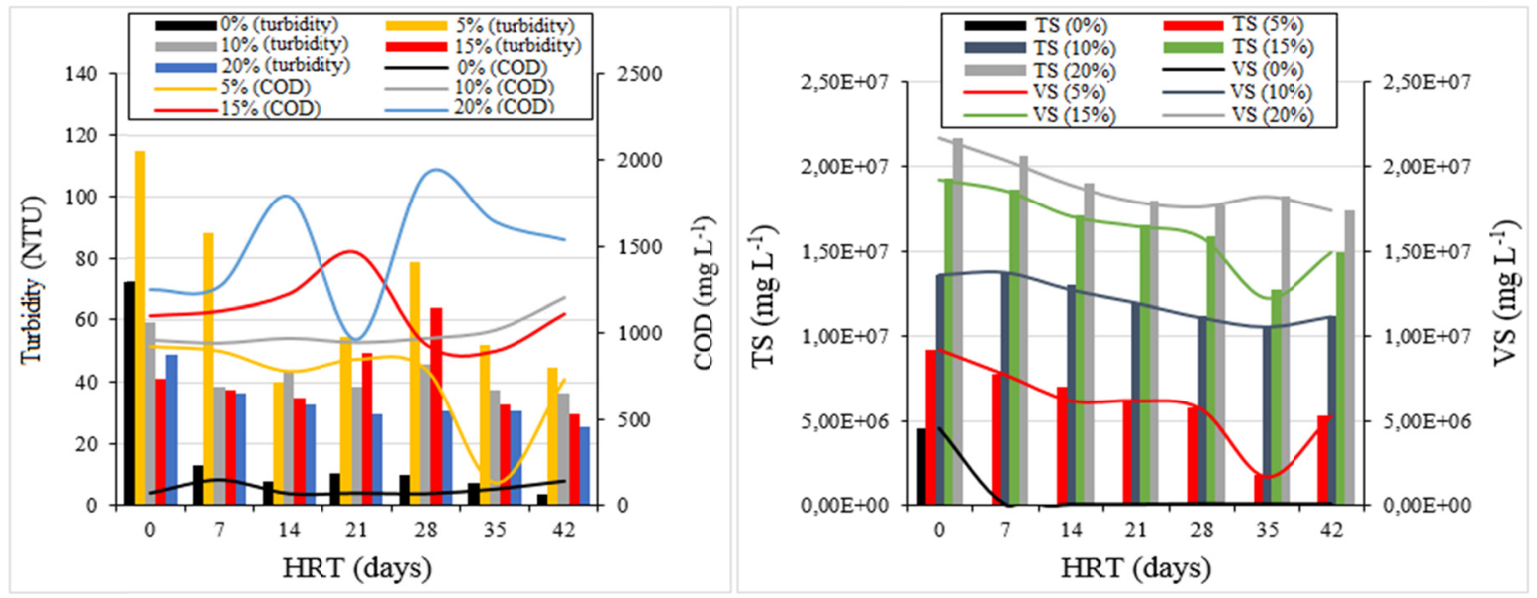

Figure 3. Turbidity (NTU) and COD ( $\left.\mathrm{mg} \mathrm{L}^{-1}\right)$ (left), VS and TS (right) during anaerobic co-digestion of industrial effluent (cellulose) with glycerin doses $\left(0,10,15\right.$ and $\left.20 \% \mathrm{v} \mathrm{v}^{-1}\right)$ during the hydraulic retention time

(HRT) of 42 days

The treatments with glycerin addition exhibited higher values for COD, this is an expected fact, since a liquid with higher turbidity and total and volatile solids tends to have higher COD values.

This occurs because COD is the parameter that indirectly represents the amount of organic compounds in the sample, measuring the necessary amount of oxygen for chemical degradation of organic matter in the liquid medium (Kolesárová et al., 2011). As the organic matter content in the glycerin treatments is higher, a proportional increase of COD values occurs in these reactors (Verussa et al., 2017).

Because of this close relationship, several authors studied the influence of COD on the production of biogas in anaerobic systems (Kolesárová et al., 2011; Fleck et al., 2017; Sumardiono et al., 2013; Ebrahimi et al., 2018).

Sunada et al. (2012), when evaluating the biogas production in the anaerobic digestion of refrigerator effluent with and without the removal of COD (solid fraction $>1 \mathrm{~mm}$ ), observed, in the treatments with initial COD removal, a decrease in the biogas production rate, while in the reactors with organic load maintenance the rate remained practically constant.

In this research, the treatments with the highest COD removal at the end of HRT are also the treatments with the highest biogas production (Dose 0\%, 5\% and 15\%). Panpong et al. (2017), in their studies, also observed that the treatments with higher COD removal produced higher amounts of biogas.

The only treatments with $\mathrm{N}$ contents were Dose $0 \%$ and 5\%, with peaks observed at 7 and 14 days (Figure 4). The low values for the $\mathrm{N}_{\text {total }}$ concentration are justified by its easy degradation in the anaerobic biodigestion process, as well by the low $\mathrm{N}_{\text {total }}$ initial values in the substrates (Sunada et al., 2012). 


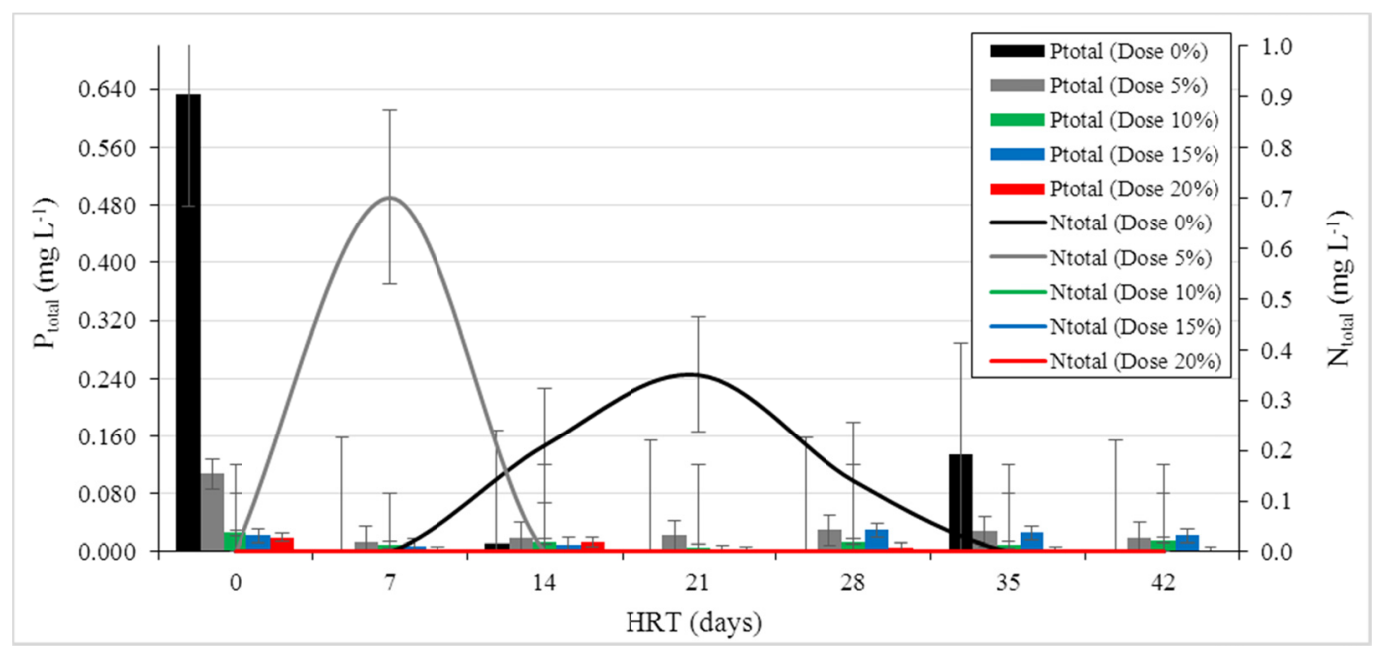

Figure 4. $\mathrm{N}_{\text {total }}$ and $\mathrm{P}_{\text {total }}\left(\mathrm{mg} \mathrm{L}^{-1}\right)$ in anaerobic biodigestion of industrial effluent (cellulose) with glycerin doses $\left(0,5,10,15\right.$ and $\left.20 \% \mathrm{v} \mathrm{v}^{-1}\right)$ during the hydraulic retention time (HRT) of 42 days

The limitation of $\mathrm{N}$ is an obstacle to the efficient biodigestion of glycerin (Aguilar et al., 2017), which molecule (propane-1,2,3-triol) is composed of carbon atoms $(\mathrm{C})$, hydrogen $(\mathrm{H})$ and oxygen $(\mathrm{O})$, without $\mathrm{N}$ in its composition.

Likewise, $\mathrm{N}$ deficiency may restrict the conversion efficiency of organic matter to biogas. Therefore, the ideal for anaerobic biodigestion and biogas production would be to use effluents with medium-high content of $\mathrm{N}$, such as the swine effluent, and glycerin, which has a high carbon content, because this way the effluent corrects the $\mathrm{N}$ restriction of glycerin. Thus, it is possible to obtain a good $\mathrm{C} / \mathrm{N}$ ratio in the final substrate, with values in the range of 20/35, causing an increase in the production of biogas (Aguilar et al., 2017).

As glycerin contains a high concentration of $\mathrm{C}$ of easy assimilation, its quality, as a co-product of anaerobic digestion, enriches the process, since $\mathrm{C}$ in more complex structures, such as long chain fatty acids, can become toxic for microorganisms. Thus, glycerin doses with animal wastes with $\mathrm{N}$ contents can balance the medium (Schwingel et al., 2017).

The concentrations of $P_{\text {total }}$ did not exhibit variations during HRT (Figure 4). For Sunada et al. (2012), an increase of the $\mathrm{N}, \mathrm{P}$ and $\mathrm{K}$ concentrations in the biofertilizer is common, because during the anaerobic digestion the majority of the $\mathrm{C}$ is lost in the form of $\mathrm{CH}_{4}$ and $\mathrm{CO}_{2}$, causing the concentration of other non-volatile elements. However, as in the present study, these authors observed a significant reduction of $\mathrm{P}_{\text {total }}$ concentrations, which, according to them, is related to the physical and chemical removal by the precipitation of these compounds (Sunada et al., 2012).

The doses of $15 \%$ and $5 \%$ of glycerin, respectively, resulted in higher rate of biogas production ( 0.543 and 0.400 $\left.\mathrm{mL} \mathrm{L}^{-1} \mathrm{~d}^{-1}\right)$. Doses higher than $15 \%$ affected the development of microorganisms and, consequently, the production of biogas (Figure 5).

Fountoulakis, Petousi, and Manios (2010) mention that when applied in adequate doses, glycerin may have represent advantage in the biodigestion process, increasing biogas production, but glycerin adding must be cautious, in order not to cause organic overload in the biodigester. It occurs that in this case the overload hinders the action of anaerobic microorganisms, making it desirable to dilute the residue, which would facilitate the process of anaerobic biodigestion (Sgorlon et al., 2011). 


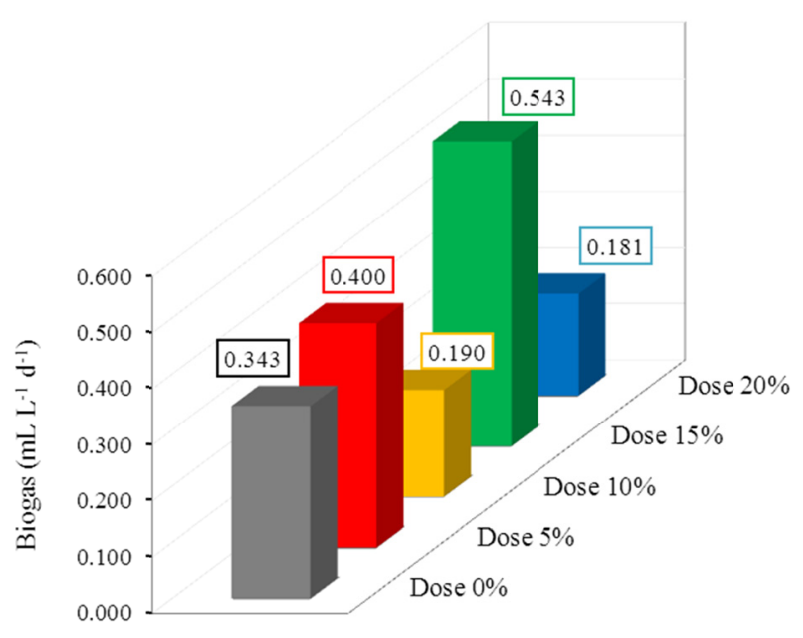

Figure 5. Biogas production rate $\left(\mathrm{mL} \mathrm{L}^{-1} \mathrm{~d}^{-1}\right)$ during the hydraulic retention time (HRT)

This subject is discussed in the studies of Astals et al. (2011), where the presence of acetic, propionic and butyric acids in the co-digestion of swine effluent associated with high levels of glycerin (80\%), being the presence of these acids the result of the lack of conditions (due to the acid medium) for the digestion of the samples. In addition, for these authors, the treatment with $80 \%$ of glycerin produced less biogas when compared to the treatment with $0 \%$.

A fundamental aspect of anaerobic biodigestion associated with glycerin is the importance of N-rich substances, due to the scarcity or absence of this nutrient in the crude glycerin, thus, for an ideal balance of $\mathrm{C} / \mathrm{N}$ ratio, in some cases, the use of $\mathrm{N}$ supplementation in the biodigester is necessary (Pazuch et al., 2017).

In order to achieve higher biogas production rates, the substrate used should exhibit carbon-nitrogen $(\mathrm{C} / \mathrm{N})$ ratio of about 30 carbon molecules by 20 nitrogen molecules (Aguilar et al., 2017).

Aguilar et al. (2017) reports the biogas production as a function of the anaerobic digestion of crude glycerin dosed in swine effluent, and for these authors, better results are observed in the mixing range between 0.4 and $0.5 \%$, resulting in an amount of $521.5 \mathrm{~mL}$ of biogas per $\mathrm{g}$ of total COD. For them the relationship between inoculum volume and the total amount of VS was adequate, and this was an important factor for biodigestion. However, in this same research, the highest COD removal occurred with the higher doses of glycerin $(0.10$ and $0.11 \%)$.

In the present study, the treatments with the highest biogas production were also the ones with the highest removal of COD, evidencing the transformation of the organic matter in liquid medium into biogas $\left(\mathrm{C}_{\text {org }}\right.$ in $\mathrm{CH}_{4}$ and $\mathrm{CO}_{2}$ ). Panpong et al. (2017) also observed such correlation between these parameters, when they studied the biogas production through the digestion of sardine processing effluent, with production up to $8.30 \%$ more biogas in relation to the treatment without glycerin, with the highest biogas production following the highest removal of COD.

In Table 2 and Figure 6 it is possible to observe that most of the studied nutrients had their levels elevated throughout HRT, Sunada et al. (2012), explains that the elevation of these levels is expected, because during digestion, $\mathrm{C}$ tends to be lost in the formation of $\mathrm{CH}_{4}$ and $\mathrm{CO}_{2}$, and in this way occurs the concentration of other nutrients.

In the treatment without addition of glycerin, where the $\mathrm{pH}$ values remained in the range of 6.16 to 6.8 , it is observed a lower availability of metals, such as $\mathrm{Fe}, \mathrm{Mn}, \mathrm{Cu}$ and $\mathrm{Zn}$, due to the formation of insoluble forms, i.e. occurrence of precipitated forms of these compounds.

The presence of certain metals in the medium may be of fundamental importance during biogas production, since methanogenesis is one of the most metal-enriched enzyme pathways in biology, however, the amount of metal required at this stage of biodigestion depends on the biochemical pathway of the biogas. However, there are trends that generally prevail. $\mathrm{Fe}$, for example, is the most required metal, followed by nickel ( $\mathrm{Ni})$ and cobalt (Co) and remnants of molybdenum (Mo) and Zn (Goswami et al., 2016). 
Table 2. Total contents of $\mathrm{K}, \mathrm{Ca}, \mathrm{Mg}, \mathrm{Cu}, \mathrm{Zn}, \mathrm{Fe}$ and $\mathrm{Mn}$

\begin{tabular}{|c|c|c|c|c|c|c|c|c|c|c|}
\hline Organic waste & $\mathrm{N}$ & $\mathrm{P}$ & $\mathrm{K}$ & $\mathrm{Ca}$ & $\mathrm{Mg}$ & $\mathrm{Cu}$ & $\mathrm{Zn}$ & $\mathrm{Fe}$ & $\mathrm{Mn}$ & Authors \\
\hline & \multicolumn{9}{|c|}{ - - } & \multirow{7}{*}{ This research } \\
\hline $\begin{array}{l}\text { Cellulose effluent }+ \text { Glycerin } \\
(\text { HRT }=7 \text { days, Dose } 0 \%)\end{array}$ & 0.00 & 0.17 & 78.71 & 171.97 & 58.36 & 0.00 & 0.26 & 0.21 & 0.44 & \\
\hline $\begin{array}{l}\text { Cellulose effluent }+ \text { Glycerin } \\
(\text { HRT }=14 \text { days, Dose } 5 \%)\end{array}$ & 0.14 & 0.01 & 91.86 & 202.01 & 65.88 & 0.00 & 0.04 & 0.18 & 0.51 & \\
\hline $\begin{array}{l}\text { Cellulose effluent }+ \text { Glycerin } \\
(\text { HRT }=21 \text { days, Dose } 10 \%)\end{array}$ & 0.04 & 0.01 & 109.59 & 212.36 & 67.42 & 0.00 & 0.01 & 0.18 & 1.52 & \\
\hline $\begin{array}{l}\text { Cellulose effluent }+ \text { Glycerin } \\
(\text { HRT }=28 \text { days, Dose } 15 \%)\end{array}$ & 0.07 & 0.005 & 131.12 & 216.80 & 63.98 & 0.00 & 0.00 & 0.20 & 0.50 & \\
\hline $\begin{array}{l}\text { Cellulose effluent }+ \text { Glycerin } \\
(\text { HRT }=35 \text { days, Dose } 20 \%)\end{array}$ & 0.03 & 0.02 & 136.32 & 207.92 & 64.47 & 0.00 & 0.04 & 0.18 & 0.23 & \\
\hline $\begin{array}{l}\text { Mean values obtained in this } \\
\text { study after } 42 \text { days of HRT }\end{array}$ & 0.04 & 0.04 & 109.52 & 202.21 & 64.02 & 0.00 & 0.07 & 0.19 & 0.64 & \\
\hline Swine waste & $19,600.00$ & $23,600.00$ & 159.10 & 27.70 & 12.20 & 30.00 & 117.00 & 303.00 & 110.00 & Bócoli et al. (2016) \\
\hline Bovine biofertilizer & 140.00 & 50.00 & 0.05 & 0.07 & 0.03 & 0.10 & 1.40 & 1.00 & 0.20 & Chicondo et al. (2013) \\
\hline STS sludge, whey industry & $6,530.00$ & 980.00 & 0.78 & 1.89 & 1.29 & 5.34 & 15.00 & 440.00 & 13.85 & Schwantes et al. (2017) \\
\hline Vinasse & 710.00 & 170.00 & & & & & & & & Silva et al. (2016) \\
\hline Bovine biofertilizer & & 60.00 & 4.33 & 6.77 & 8.50 & & & & & Ferreira et al. (2015) \\
\hline Cattle manure & 780.00 & 730.00 & 1.19 & 0.59 & 0,28 & 2.04 & 5.90 & 73.04 & 9.32 & Alencar et al. (2015) \\
\hline $\begin{array}{l}\text { Spraying, urine and dietary } \\
\text { remains of dairy cows }\end{array}$ & $4,250.00$ & 20.00 & 0.13 & 0.30 & 0.37 & & & & & Soares Filho et al. (2015) \\
\hline
\end{tabular}

Note. Total contents of $\mathrm{K}, \mathrm{Ca}, \mathrm{Mg}, \mathrm{Cu}, \mathrm{Zn}, \mathrm{Fe}$ and $\mathrm{Mn}$ of cellulose industry effluent and glycerin, and comparison with other organic wastes.

In addition to being used in electron transport, $\mathrm{Fe}$ is a constituent of the metalloenzymes involved in methanogenesis, in the form of $\mathrm{Fe}_{2} \mathrm{~S}_{2}, \mathrm{Fe}_{3} \mathrm{~S}_{2}$ or $\mathrm{Fe}_{4} \mathrm{~S}_{2}$ (Rao et al., 2011). Another important element is $\mathrm{Ca}$, this macronutrient when in the substrate contributes to $\mathrm{pH}$ equilibrium by neutralizing $\mathrm{H}^{+}$, thus avoiding intensive acidification of the medium (Matheri et al., 2016). On the other hand, Suárez et al. (2014) states that excess of $\mathrm{Ca}$ can inhibit biogas production by favoring the precipitation of carbonate and calcium phosphate, which can result, for example, in the loss of buffer capacity and essential nutrients for anaerobic digestion.

It is also necessary to be cautious about $\mathrm{Zn}$, because in high concentrations it can cause toxicity to the microorganisms, inhibiting important biochemical reactions. However, adequate levels of $\mathrm{Zn}$ have been shown to potentiate the formation of $\mathrm{CH}_{4}$ (Matheri et al., 2016).

The $\mathrm{Mn}$ is another element that can positively interfere in the production of biogas, since besides accelerating the methanogenesis, can increase the final produced volume. In addition, the element can also serve as an oxidizing agent to donate electrons to form methane from carbon dioxide (Qiao et al., 2015). 

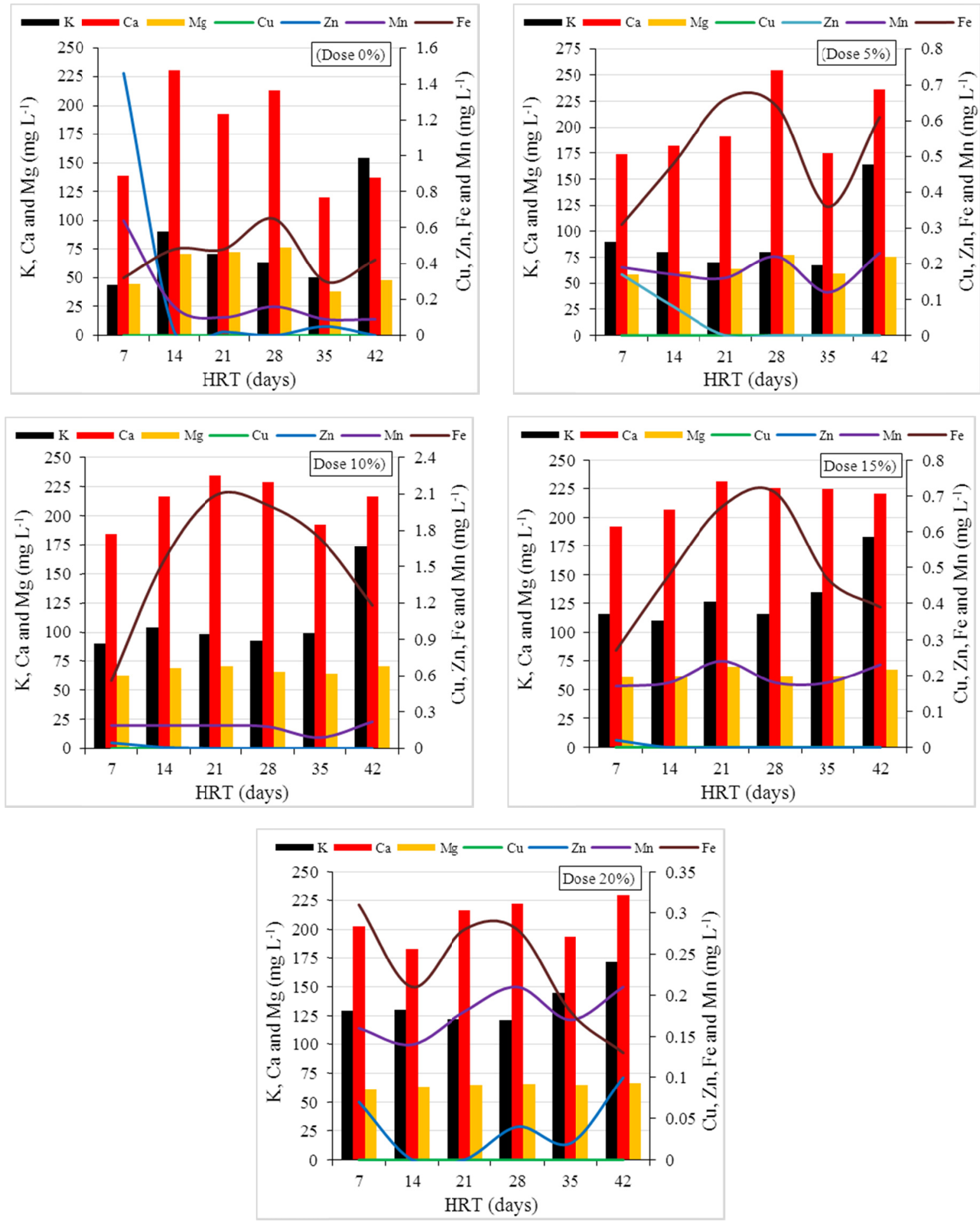

Figure 6. Levels of $\mathrm{K}, \mathrm{Ca}, \mathrm{Mg}, \mathrm{Cu}, \mathrm{Zn}, \mathrm{Fe}$ and $\mathrm{Mn}\left(\mathrm{mg} \mathrm{L}^{-1}\right)$ in anaerobic biodigestion of industrial effluent (cellulose) with glycerin doses $\left(0,5,10,15\right.$ and $\left.20 \% \mathrm{v} \mathrm{v}^{-1}\right)$ during the hydraulic retention time (HRT) of 42 days

$\mathrm{Mg}$ acts as a necessary enzymatic cofactor in the stabilization of nucleotides and nucleic acids. It is related to enzymatic reactions associated with energy transfer and phosphorylation/dephosphorylation. It occurs that much of the energy of the cell is stored in the form of ADP and ATP, for this energy to be released the presence of $\mathrm{Mg}$ is fundamental, as it assists in the formation of a "bridge" between the oxygen atoms of two adjacent phosphate groups and an $\mathrm{N}$ atom at the catalytic site of the protein (Suárez et al., 2014). 
Similarly, $\mathrm{K}^{+}$ions also are not directly involved in methanogenesis, however, a large part of the methanogenic enzymes exert their function effectively when $\mathrm{K}^{+}$is present in the medium at high concentrations (Glasemacher et al., 1996).

Since several soils have micronutrient deficiency (Silva et al., 2014), the final concentrations of these in the biofertilizer, although not expressive, are a good alternative for supplying $\mathrm{Zn}, \mathrm{Fe}, \mathrm{Mn}, \mathrm{K}, \mathrm{Ca}$ and $\mathrm{Mg}$ to the soil, without causing toxicity to the plants.

Anaerobic digestion of the cellulose industry effluent with 5 and $15 \%$ of glycerin $\left(\mathrm{v} \mathrm{v}^{-1}\right)$ provided a satisfactory increase in biogas production ( 0.54 and $0.40 \mathrm{~mL} \mathrm{~L}^{-1} \mathrm{~d}^{-1}$, respectively).

Anaerobic digestion provided considerable reductions for TS and VS, confirming the feasibility of using biodigesters as treatment of these residues.

The concentrations of $\mathrm{P}$ were reduced during HRT, and the nutrients ( $\mathrm{K}, \mathrm{Ca}, \mathrm{Mg}, \mathrm{Zn}, \mathrm{Fe}$ and $\mathrm{Mn}$ ), although with high levels during the process (which is considered normal by several authors) are in adequate concentrations for use in crops as biofertilizer.

\section{Acknowledgements}

To the Fundação Araucária for the funding of this research.

\section{References}

Aguilar-Aguilar, F. A., Nelson, D. L., Pantoja, L. A., \& Santos, A. S. (2017). Study of anaerobic co-digestion of crude glycerol and swine manure for the production of biogas. Rev. Virtual Quim, 9(6), 2383-2403. https://doi.org/10.21577/1984-6835.20170142

Alencar, T. L., Chaves, A. F., Santos, C. L. A., Assis Júnior, R. N., Mota, J. C. A. (2015). Physical properties of a cultivated cambisol treated with biofertilizer in the apodi plateau, Ceará, Brazil. Rev. Bras. Ciênc. Solo. 39(3), 737-749. https://doi.org/10.1590/01000683rbcs20140437

APHA. (2012). Standard Methods for the Examination of Water and Wastewater.

Astals, S., Ariso, M., Galí, A., \& Mata-Alvare, J. (2011). Co-digestion of pig manure and glycerine: experimental and modelling study. J Environ Manage, 92(1), 1091-1096. https://doi.org/10.1016/j.jenvman.2010.11.014

Awe, O. W., Lu, X., Wu, S., Zhao, Y., Nzihou, A., Lyczko, N., \& Mi, D. P. (2017). Effect of oil content on biogas production, process performance and stability of food waste anaerobic digestion. Waste Biomass Valori, 9(7), 1223-1230. https://doi.org/10.1007/s12649-017-0179-4

Bócoli, M. E., Mantovani, J. R., Miranda, J. M., Marques, D. J., \& Da Silva, A. B. (2016). Soil chemical properties and maize yield under application of pig slurry biofertilizer. Rev Bras Eng Agr Amb, 20(1), 42-48. http://doi.org/10.1590/1807-1929/agriambi.v20n1p42-48

BRACELPA. (2017). Brazilian Cellulose and Paper Association. Retrieved from http://www.bracelpa.org.br/br a2/sites/default/files/estatisticas/rel2012.pdf

Calli, B., Mertoglu, B., Inanc, B., \& Yenigun, O. (2005). Effect of high free ammonia concentrations on the performances of anaerobic bioreactors. Process Biochemistry, 40(3-4), 1285-1292. https://doi.org/10.1016/ j.procbio.2004.05.008

CETESB. (2008). Environmental Sanitation Technology Company, Environmental Technical Guide for Pulp and Paper-Série $P+L$. Retrieved from http://www.fiesp.com.br/arquivo-download/?id=4281

Chiconato, D. A., De Simoni, F., Galbiatti, J. A., Franco, C. F., \& Caramelo, A. D. (2013). Response of the lettuce to the application of biofertilizer under two levels of irrigation. Biosci. J., 29(2), 392-399.

Ebrahimi, A., Hashemib, H., Eslamic, H., Fallahzadeha, R. A., Khosravid, R., Askarie, R., \& Ghahramani, E. (2018). Kinetics of biogas production and chemical oxygen demand removal from compost leachate in an anaerobic migrating blanket reactor. J Environ Manage, 15(206), 707-714. https://doi.org/10.1016/ j.jenvman.2017.10.038

Ferreira, N. M, Mesquita, E. F., Sá, F. V. da S., Bertino, A. M. P., Paiva, E. P. P., \& Farias, S. A. R. (2015). Growth and production of castor bean BRS Paraguaçu under irrigation, soil mulching and organic fertilization. Rev. Bras. Eng. Agr. Amb., 19(9), 857-864. https://doi.org/10.1590/1807-1929/agriambi. v19n9p857-864 
Fleck, L., Tavares, M. H. F., Eyng, E., Andrade, M. A. de M. de, \& Frare, L. M. (2017). Optimization of anaerobic treatment of cassava processing wastewater. Eng. Agríc., 37(3), 574-590. https://doi.org/10.1590/ 1809-4430-eng.agric.v37n3p574-590/2017

Fountoulakis, M. S., Petousi, I., \& Manios, T. (2010). Co-digestion of sewage sludge with glycerol to boost biogas production. Waste Manage, 30(10), 1849-1853. https://doi.org/10.1016/j.wasman.2010.04.011

Glasemacher, J., Siebers, A., Altendorf, K., \& Schönheit, P. (1996). Low-affinity potassium uptake system in the archaeon Methanobacterium thermoautotrophicum: Overproduction of a 31-kilodalton membrane protein during growth on low-potassium medium. $J$ Bacteriol, 178(3), 728-734. https://doi.org/10.1128/jb.178. 3.728-734.1996

Goswami, R., Chattopadhyay, P., Shome, A., Banerjee, S. N., Chakraborty, A. K., \& Mathew, A. K. (2016). An overview of physico-chemical mechanisms of biogas production by microbial communities: a step towards sustainable waste management. 3 Biotech, 6(72), 1-12. https://doi.org/10.1007/s13205-016-0395-9

Jerônimo, C. E. M., Fernandes, H. G., Melo, H. N. S., Sousa, J. F. (2012). Bioaccumulation effluent degradation for the processing of cashew nuts. Holos, 3(28), 47-59. https://doi.org/10.15628/holos.2012.829

Kolesárová, N., Hutňan, M., Bodík, I., \& Špalková, V. (2011). Utilization of biodiesel by-products for biogas production. J Biomed Biotechnol, 1-15. https://doi.org/10.1155/2011/126798

Larsen, A. C., Gomes, B. M., Gomes, S. Sd., Zenatti, D. C., \& Torres, D. G. B. (2013). Anaerobic co-digestion of crude glycerin and starch industry effluent. Eng. Agric., 33(2), 341-352. https://doi.org/10.1590/S0100-6916 2013000200013

Matheri, A. N., Belaid, M., Seodigeng, T., \& Ngila, G. C. (2016). The role of trace elements on anaerobic co-digestion in biogas production. Proceedings of the World Congress on Engineering, London, 2, 1-6.

Montebello, A. E. S., \& Bacha, C. J. C. (2013). Impactos da Reestruturação do Setor de Celulose e Papel no Brasil sobre o Desempenho de suas Indústrias. Estudos Economicos, 43(1), 109-137. https://doi.org/ $10.1590 / \mathrm{S} 0101-41612013000100005$

Orrico Junior, M. A. P., Schwingel, A. W., Centurion, S. R., \& Orrico, A. C. A. (2016). Co-digestion of swine excreta associated with increasing levels of crude glycerin. R. Bras. Zootec, 45(3), 101-106. https://doi.org/10.1590/S1806-92902016000300003

Panpong, K., Srimachai, T., Nuithitikul, K., Kongjan, P., O-Thong, S., Imai, T., \& Kaewthongi, N. (2017). Anaerobic co-digestion between canned sardine wastewater and glycerol waste for biogas production: Effect of different operating processes. Energy Procedia, 138, 260-266. https://doi.org/10.1016/j.egypro. 2017.10.050

Pazuch, F. A., Siqueira, J., Friedrich, L., Lenz, A. M., Nogueira, C. E. C., \& De Souza, S. N. M. (2017). Co-digestion of crude glycerin associated with cattle manure in biogas production in the State of Paraná, Brazil. Acta Sci-Technol, 39(2), 149-159. https://doi.org/10.4025/actascitechnol.v39i2.29167

Priadi, C., Wulandari, D., Rahmatika, I., \& Moersidik, S. S. (2014). Biogas production in the anaerobic digestion of paper sludge. APCBEE Procedia, 9, 65-69. https://doi.org/10.1016/j.apcbee.2014.01.012

Qiao, S., Tian, T., Qi, B., \& Zhou, J. (2015). Methanogenesis from wastewater stimulated by addition of elemental manganese. Scientific Reports, 5, 12732. https://doi.org/10.1038/srep12732

Rao, A. G., Prakash, S. S., Joseph, J., Reddy, A. R., \& Sarma, P. N. (2011). Multi stage high rate biomethanation of poultry litter with self mixed anaerobic digester. Bioresour Technol, 102, 729-735. https://doi.org/ 10.1016/j.biortech.2010.08.069

Ruiz, U. R., Thomaz, M. C., Júnior, J. L., Pascoal, L. A. F., Watanabe, P. H., Amorim, A. B., ... Silva, A. A. (2017). Enzyme complex supplementation in different nutrient levels diets on pigs feces excretion and anaerobic digestion. Sci. Agric., 74(3), 180-188. https://doi.org/10.1590/1678-992x-2016-0073

Schwantes, D., Gonçalves Jr., A. C., Richart, A., Schulz, L., Manfrin, J., Schiller, A. P., \& Schulz, E. (2017a). Biofertilization of tifton 85 with sludge from sewage treatment station of whey industry. IJPSS, 16, 1-10. https://doi.org/10.9734/IJPSS/2017/33549

Schwingel, A. W., Orrico, A. C. A., Junior, M. A. P. O., Sunada, N. S., \& Centurion, R. S. (2016). Performance of the anaerobic co-digestion of pig manure with the inclusion of crude glycerine. Rev Cienc Agron, 47(4), 778-783. https://doi.org/10.5935/1806-6690.20160093 
Sgorlon, J. G., Rizk, M. C., Bergamasco, R., \& Tavares, C. R. G. (2011). Evaluation of the COD and the C/N ratio in the anaerobic treatment of fruit and vegetable wastes. Acta Sci-Technol, 33(4), 421-424.

Shah, F. A., Mahmood, Q., Shah, M. M., Pervez, A., \& Asad, S. A. (2014). Microbial ecology of anaerobic digesters: The key players of anaerobiosis. The Scientific World Journal, 1-21. https://doi.org/10.1155/2014/ 841549

Silva, A. A., Couto Jr, P. A., Lana, A. M. Q., \& Lana, R. M. Q. (2014). Oil and leaf micronutrient concentration with the application of sulfate and chelated sources and in common bean. Eng. Agr., 34(1), 28-37. https://doi.org/10.1590/S0100-69162014000100004

Silva, C. E. F., \& Abud, A. K. S. (2016). Anaerobic biodigestion of sugarcane vinasse under mesophilic conditions using manure as inoculum. Rev. Ambient. Água., 11(4), 763-777. https://doi.org/10.4136/ ambi-agua. 1897

Simm, S., Orrico, A. C. A., Junior, M. A. P. O., Sunada, N. S. S., Scwingel, A. W., \& Costa, M. S. S. M. (2017). Crude glycerin in anaerobic co-digestion of dairy cattle manure increases methane production. Sci. Agric., 74(3), 175-179. https://doi.org/10.1590/1678-992x-2016-0057

Soares Filho, C. V., Heinrichs, R., Perri, S. H. V., Correia, A. C. (2015). Chemical atributes in soil and production of "Cynodon dactylon" cv. Tierra Verde on doses of organic biofertilizer. Rev. Bras. Saúde Prod. Anim, 16(1), 23-35.

Suárez, A. G., Nielsen, K., Köhler, S., Merencio, D. O., \& Reyes, I. P. (2014). Enhancement of anaerobic digestion of microcrystalline cellulose (MCC) using natural micronutrient sources. Braz. J. Chem. Eng, 31(2), 393-401. https://doi.org/10.1590/0104-6632.20140312s00002689

Sumardiono, S., Syaichurrozi, I., \& Sasongko, S. B. (2013). The Effect of COD/N Ratios and pH control to biogas production from vinasse. Int J Biochem Res Rev, 3(4), 401-413. https://doi.org/10.9734/IJBCRR/ 2013/3797

Sunada, N. S., Orrico, A. C. A., Orrico Júnior, M. A. P., Vargas Junior, F. M., Garcia, R. G., \& Fernandes, A. R. M. (2012). Potential of biogas and methane production from anaerobic digestion of poultry slaughterhouse effluent. R. Bras. Zootec., 41(11), 2379-2383. https://doi.org/10.1590/S1516-35982012001100013

Verussa, G. H., Corassa, A. C., Pina, D. do S., Ton, A. P. S., Komiyama, C. M., \& Teixeira, A. de O. (2017). Nutritional value of glycerin for pigs determined by different methodologies. R. Bras. Zootec., 46(7), 584-590. https://doi.org/10.1590/s1806-92902017000700005

\section{Copyrights}

Copyright for this article is retained by the author(s), with first publication rights granted to the journal.

This is an open-access article distributed under the terms and conditions of the Creative Commons Attribution license (http://creativecommons.org/licenses/by/4.0/). 